\title{
The Reasons of Job Alienation among the Faculty Members of Hebron \& Al-Quds Universities
}

\author{
Jafar W. Abu Saa ${ }^{1, *} \&$ Mahmoud A. Abu Samra ${ }^{2}$ \\ ${ }^{1}$ Faculty of Arts and Educational Sciences, Palestine Technical University-Kadoorie, Tulkarem, Palestine \\ ${ }^{2}$ Faculty of Educational Sciences, Al-Quds University, Jerusalem, Palestine \\ *Correspondence: Faculty of Arts and Educational Sciences, Palestine Technical University-Kadoorie, P.O. Box 7, \\ Tulkarem, Palestine. Tel: 972-594-222-637. E-mail: jaafarabusaa@yahoo.com
}

Received: March 2, $2019 \quad$ Accepted: March 22, $2019 \quad$ Online Published: April 8, 2019

doi:10.5430/wje.v9n2p65 URL: https://doi.org/10.5430/wje.v9n2p65

\begin{abstract}
The present study aimes to identify the reasons behind experiencing job alienation by the faculty members at Hebron \& Al-Quds universities. It was conducted during the second semester of the academic year (2017/2018). The study's population involves all the faculty members who work at Hebron \& Al-Quds universities (i.e. 446 faculty members). The study's sample consists of (200) faculty members. Those members were selected through using the random stratified sampling method. The study's instrument was developed by the researchers, and It is represented in a questionnaire. The questionnaire seeks to identify the reasons behind experiencing job alienation by the faculty members at Hebron \& Al-Quds universities. It consists of (20) statements. These statements address two types of reasons; a)-reasons that are related to the university management \& b)- reasons that are related to the work colleagues. The researchers checked the validity of questionnaire, and they measured the reliability of the questionnaire through using the relevant statistical methods. It was found that the statements that concern the examined reasons show moderate means. In addition, it was found that there is not any statistically significant difference between the respondents' attitudes which can be attributed to the university.
\end{abstract}

Keywords: job alienation, faculty members, Hebron University, Al-Quds University

\section{Introduction}

Alienation is a phenomenon that can be experienced in several aspects of life, such as: the social, economic, and political aspects. Karl Marx was the first one who aimed to shed light on the latter phenomenon in terms of origin and development. He perceived this phenomenon as a socio-historical phenomenon. Hegel's works led Marx to pay attention to the concept of "Alienation". These works provided Marx with foundations that enabled him to form his socio-political ideology about citizenship alienation. The latter ideology led Marx to propose the term (job alienation) (Abed Al-Salam, 2003). It should be noted that job alienation indicates that there is a weak relationship between the employee and his/her employer.

Job alienation in institutions is considered a serious phenomenon. That's because it negatively affects the employee's relationship with the institution that he/she works at. In addition, it negatively affects the employee's loyalty to the institution that he/she works at. If the employee experiences job alienation, there shall be serious consequences affecting the employee $\&$ the institution. Experiencing job alienation often ends in a bad situation occurring between the employee and his/her employer (Al-Mutrufy, 2005).

Job alienation negatively affects the employee's performance. There is no doubt that having a high job alienation level and a low job satisfaction level will negatively affect job-related aspects. Such aspects include: absence from work, the employee relationship with colleagues, management and leadership, and job turnover. Such aspects include absence from work based on false justifications, such as: a false claim of being sick and etc.

It is important to identify the job alienation level of employees in general. However, it is more important to identify the job alienation level of the academics who work at academic institutions, especially at univresities. That is because academics play a significant role in setting and implementing programs that participate in developing future generations and public institutions and their employees. In other words, academics play a significant role in 
developing humans in cognitive, physical, spiritual, and emotional areas.

Job alienation is considered a very important phenomenon due to its impact on institutions, individuals and societies. However, as far as the researchers know, the studies that shed light on job alienation of academics are still scarce. Therefore, the present study aimes to explore the reasons behind experiencing job alienation by faculty members at Palestinian universities through selecting Hebron \& Al-Quds universities as models.

\section{Problem and Questions of the Study}

Job alienation -regardless of its form or type -is considered as a very important and serious phenomenon. That is because it is experienced by many employees- including the academics who work at universities. It should be noted that this phenomenon is worth studying because it exists in most societies. It is also because it has a negative impact on job-related aspects and psychological aspects.

The researchers aimes to shed light on this phenomenon because they believe that this phenomenon affects job loyalty. They also believe that job loyalty is very important. For instance, having a high job loyalty level is considered as a requirement for achieving success in an administrative job. The higher the job alienation level of the employee, the lower his/her job performance level will be. Based on the aforementioned, it is necessary to explore the reasons behind experiencing job alienation by academics in academic institutions, especially the Palestinian universities. Abu Samra et al. (2014) suggest that the faculty members at Hebron \& Al-Quds universities experience a high job alienation level. Therefore, the present study aims to identify the reasons behind experiencing job alienation by the faculty members at Hebron \& Al-Quds universities through proposing the following questions:

The first question is, "What are the reasons behind experiencing job alienation by the faculty members at Hebron \& Al-Quds universities?"

The second question is, "Is there any statistically significant difference between the respondents' attitudes which can be attributed to the university?"

\section{Theoretical Background}

Job alienation is considered a serious phenomenon. If the employees show a high job alienation level, it indicates that the institution is going through a serious crisis. Such a crisis may lead the institution to experience failure and decline. Job alienation means that the employee believes that the institution he/she works at is not the suitable workplace any more for him/her. Having such a belief is often attributed to institution-related reasons, rather than employee-related reasons. Job alienation affects the relationship between the employee and his/her employer. It also affects the job loyalty of the employee. It will lead to serious consequences affecting the employee \& the institution. Experiencing job alienation often ends in a bad situation occurring between the employer and the employee, which in turn leads to terminating the employee-employer relationship (Al-Mutrufy, 2005).

Organizations today suffer from experiencing low job satisfaction, loyalty, \& low organizational loyalty by their employees. These negative feelings can be attributed to job alienation. For instance, if an employee doesn't feel motivated to work in a certain job, he/she shall experience such negative feelings (Zalikha, 2012).

\subsection{The Reasons of Job Alienation}

There are various reasons that can lead one to experience alienation in general and job alienation in spesific. There are two types of reasons; a)-reasons that are related to the institution itself $\&$ b)- reasons that are related to the one's self. The latter reasons may include reasons attributed to work colleagues. They may also include: economic, political, social and religious reasons (Moussa, 2003; Awaad, 2011). Job alienation can be attributed to two types of reasons; a)-reasons that are related to the institution itself \& b)- reasons that are related to the work colleagues.

\subsubsection{Reasons that Are Related to the Institution Itself}

A. The poor leadership competencies of leaders

The most important include the poor leadership competencies of leaders. They also include the poor administrative skills of leaders (Al-Hawari, 2000). reasons leading to job alienation

\section{B. The poor reporting of employee performance}

If the annual reporting of employee performance is not based on objective standards, the employees' feelings and performance will be negatively affected. That is because such reporting will be made through carrying out a subjective assessment by direct supervisors. Such reporting is usually based on personal preferences (Al-Ghamri, 
2002)

\section{Poor incentive code}

The most important reasons leading to job alienation include having a vague incentive code. They also include applying this code in a manner that is based on favoritism and personal relationships between the employees and the top management (Schacht, 2002).

\section{Refraining from sharing information and expertise with employees}

The reasons leading to job alienation include refraining from sharing information and expertise with employees. They also include having leaders, supervisors, and employees possessing much experience who refrain from training employees and sharing information with them (Sotani \& Valkhani, 2015)

E. The size of the institution

The size of the institution affects the job alienation level. For instance, managers in the big-sized institutions will suffer from dispersion of efforts. That is because they have multiple goals to meet. Such goals include: goals related to administration and enforcing control over technical matters in the institution. In such a case, the employee may feel that he/she is not being supervised by his immediate supervisor or the one who works on his/her behalf (Al-Esawi, 1997).

\subsubsection{Reasons That Are Related to the Employees (individuals)}

A. Fear and lack of job security

If the employee is experiencing fear and lack of job security, he/she will seek running away from such feelings and avoiding them. Which in turn may lead him/her to experience dispersion of efforts during the working hours. That will lead to increasing the feeling of job alienation (Al-Dosary, 2011).

B. Lack of competency

If the employees have low competency, they will show low job performance level. Which will make them experience job alienation. In such a case, they will attribute their low performance to institution-related reasons (Al-Esawi, 1997).

C. Spare time

If the employees have much spare time, their side-talks will increase.

D. Employee poor adaptation and low compatibility with other employees

If the employee shows poor adaptation, and low compatibility with others, he/she will feel neglected inside the organization. In such a case, he/she will believe that the problems he/she suffers from are attributed to the institution itself (Al-Mutrufy, 2005)

E. The employees' values and attitudes

Job alienation may be experienced because the institution's values, regulations and goals are not consistent with the employee's values and attitudes. Job alienation may be experienced because the employee seeks meeting a goal that is undesired by the institution. Job alienation may be experienced because the employee is not getting the attention he/she deserves. Job alienation may be experienced because the institution does not seek meeting nor identifying the employee's needs and desires (Al-Kuabisi, 2003).

\subsection{Job Alienation in the Higher Education Institutions}

It is important to identify the job alienation level of the academics who work in academic institutions, especially in universities. In addition, it is important to identify the reasons behind experiencing job alienation by the faculty members at universities. Identifying such reasons will enable decision makers to improve the performance level of the faculty members at universities. That will participate in raising the performance level of universities. If the employee experiences a high job alienation level and a low job satisfaction level, he/she will not feel motivated to work. In such a case, he will show a low productivity level, and the employee's morale will decrease.

After the researchers reviewed the relevant literature, they found that there are many studies that aimed to shed light on job alienation. For instance, Saeed (2017) aimed to explore the relationship between job alienation and organizational citizenship behavior among the employees who work at the Ministry of Awqaf and Religious Affairs. He found that the job alienation level of the latter employees is high. He recommends empowering the latter employees and promoting a sense of self-trust among them. He also recommends providing those employees with 
more powers.

Glaighem (2015) aimed to identify the job alienation level of the employees at the Passport Department. He aimed to identify the extent of empowering them. It was found that job alienation level of the latter employees is moderate. The latter researcher recommends increasing the powers and responsibilities of the latter employees in a manner that reduces their job alienation level.

Nazem \& Eimani (2014) aimed to identify the factors that affect the job alienation level of the employees who work at Islamic Azad University. They found that the job alienation level of men is greater than the counterpart level of women. They recommend setting a new retirement policy, and a new policy for the complaints filed against coercive measures.

\section{The Study's Approach}

In order to meet the study's goals, the researchers adopted a descriptive approach. Through this approach, data was collected, analyzed, organized and interpreted.

\subsection{The Study's Population and Sample}

The study's population involves all the faculty members who work at Hebron \& Al-Quds universities (i.e. 446 faculty members). The study's sample consists of (200) faculty members. Those members were selected through using the random stratified sampling method.

\subsection{The Study's Instrument}

The study's instrument was developed by the researchers. It is represented in a questionnaire. This questionnaire aims to identify the reasons of job alienation. It consists of (20) statements. These statements address two types of reasons; a)-reasons that are related to the university management \& b)- reasons that are related to the work colleagues.

The researchers checked the questionnaire's validity. That was done through passing the questionnaire to (12) experts. Those experts are faculty members who work at Palestinian universities. The researchers measured the questionnaire's reliability. That was done through calculating the total value of Cronbach Alpha coefficient. The latter value is 0.91 . It indicates that the questionnaire is highly reliable.

\section{Data Statistical Analysis}

The collected data was analyzed statistically through using the SPSS software. Means were calculated to identify the reasons behind experiencing job alienation by the faculty members at Hebron \& Al-Quds universities. Means were classified based on the following criteria:

- Low: Less than (2.34).

- Moderate: (2.34 -3.67).

- High: More than (3.67).

\section{Results and Discussion}

6.1 Results Related to the First Question: "What are the reasons behind experiencing job alienation by the faculty members at Hebron \& Al-Quds universities?"

Arithmetic means and standard deviations were calculated to identify the types of reasons behind experiencing job alienation by the faculty members at Hebron \& Al-Quds universities. That was done to provide an answer to the first question. These values are presented in table 1, below: 
Table 1. Arithmetic Means and Standard Deviations of the Types of Reasons Behind Experiencing Job Alienation by the Faculty Members at Hebron \& Al-Quds Universities

\begin{tabular}{lllll}
\hline No. & Areas & Arithmetic mean & Standard deviation & Level \\
\hline 1 & $\begin{array}{l}\text { Reasons that are related to the } \\
\text { university management }\end{array}$ & $\mathbf{3 . 2 4}$ & $\mathbf{0 . 8}$ & Moderate \\
2 & $\begin{array}{l}\text { Reasons that are related to the } \\
\text { work colleagues }\end{array}$ & $\mathbf{3 . 5 0}$ & $\mathbf{0 . 1 5}$ & Moderate \\
\hline & Total & $\mathbf{3 . 3 7}$ & $\mathbf{0 . 1 2}$ & Moderate \\
\hline
\end{tabular}

Through table 1, it can be noticed that the overall mean is (3.34), which is moderate. The overall standard deviation is $(0.12)$ Each type of reasons shows a moderate mean. Regarding the respondents' attitudes, they are presented in table 2 and table 3

A. Reasons that are related to the university management:

Table 2. Arithmetic Means and Standard Deviations of the University Management-Related Reasons Leading the Faculty Members at Hebron \& Al-Quds Universities to Experience Job Alienation

\begin{tabular}{|c|c|c|c|c|}
\hline Rank. & Statement & $\begin{array}{l}\text { Arithmetic } \\
\text { mean }\end{array}$ & $\begin{array}{l}\text { Standard } \\
\text { deviation }\end{array}$ & Level \\
\hline 1 & $\begin{array}{l}\text { The superiors detract from their subordinates' } \\
\text { capabilities }\end{array}$ & 3.59 & 1.03 & Moderate \\
\hline 2 & $\begin{array}{l}\text { The job-related tasks at the university aren't } \\
\text { allocated in a fair manner }\end{array}$ & 3.58 & 0.95 & Moderate \\
\hline 3 & $\begin{array}{l}\text { The university isn't keen at raising the } \\
\text { academic performance of its students }\end{array}$ & 3.57 & 1.17 & Moderate \\
\hline 4 & $\begin{array}{l}\text { The top management positions can be held only } \\
\text { by specific employees at the university }\end{array}$ & 3.42 & 1.31 & Moderate \\
\hline 5 & $\begin{array}{l}\text { The university adopts subjective recruitment } \\
\text { standards }\end{array}$ & 3.34 & 1.04 & Moderate \\
\hline 6 & $\begin{array}{l}\text { The university employees are assessed based on } \\
\text { subjective criteria }\end{array}$ & 3.31 & 1.10 & Moderate \\
\hline 7 & $\begin{array}{l}\text { The university management overlooks the } \\
\text { errors committed by certain employees }\end{array}$ & 3.20 & 1.15 & Moderate \\
\hline 8 & $\begin{array}{l}\text { Powers are delegated at the university based on } \\
\text { subjective standards }\end{array}$ & 3.17 & 1.06 & Moderate \\
\hline 9 & $\begin{array}{l}\text { The university management responds to the } \\
\text { claims made by specific employees only }\end{array}$ & 3.04 & 1.16 & Moderate \\
\hline 10 & $\begin{array}{l}\text { The university's financial policy doesn't } \\
\text { promote job stability among employees }\end{array}$ & 2.92 & 1.26 & Moderate \\
\hline 11 & $\begin{array}{l}\text { The university management doesn't seek } \\
\text { engaging employees in the decision-making } \\
\text { process }\end{array}$ & 2.86 & 1.23 & Moderate \\
\hline \multirow[t]{2}{*}{12} & $\begin{array}{l}\text { The bonus policy of the faculty members isn't } \\
\text { fair }\end{array}$ & 2.85 & 1.10 & Moderate \\
\hline & Total & 3.23 & 0.15 & Moderate \\
\hline
\end{tabular}

Table 2 shows means \& standard deviation calculated for identifying the university management-related reasons leading the faculty members at Hebron \& Al-Quds universities to experience job alienation. Table 2 shows that:

- All the means that concern the university management-related reasons are moderate

- The statement that states "The superiors detract from their subordinates' capabilities" shows a moderate mean of (3.59). This mean is ranked first. The standard deviation of the latter statement is (1.03). The statement that states (The bonus policy of the faculty members isn't fair) shows a moderate mean of (2.85). This mean is ranked last. The standard deviation of the latter statement is (1.10). These results are attributed to the fact that the management of Hebron \& Al-Quds universities don't seek meeting the expectations of the faculty members. These expectations 
concern bonuses, incentives and rewards. That makes the faculty members feel that the management expects them to make great achievements without providing them with a reward. That will weaken their motivation to work and negatively affect their job performance. These results may be attributed to the fact that the management is not fair in the way it allocates the job-related tasks. That will lead to having a stressful workload imposed on the faculty members, which in turn will decrease the job performance of the faculty members leading them to experience job alienation.

B. Reasons that are related to the work colleagues:

Table 3. Arithmetic Means and Standard Deviations of the Work Colleagues-Related Reasons Leading the Faculty Members at Hebron \& Al-Quds Universities to Experience Job Alienation

\begin{tabular}{|c|c|c|c|c|}
\hline Rank. & Statement & $\begin{array}{l}\text { Arithmetic } \\
\text { mean }\end{array}$ & $\begin{array}{l}\text { Standard } \\
\text { deviation }\end{array}$ & Level \\
\hline 1 & $\begin{array}{l}\text { Appreciation and mutual respect are absent between } \\
\text { the work colleagues at the university }\end{array}$ & 3.91 & 0.93 & High \\
\hline 2 & $\begin{array}{l}\text { The co-workers refrain from providing help to the } \\
\text { ones who need it }\end{array}$ & 3.83 & 0.98 & High \\
\hline 3 & $\begin{array}{l}\text { There isn't a family atmosphere in the workplace at } \\
\text { the university }\end{array}$ & 3.67 & 1.12 & Moderate \\
\hline 4 & $\begin{array}{l}\text { I am forced to work with work colleagues that I } \\
\text { don't feel comfortable working with }\end{array}$ & 3.64 & 1.11 & Moderate \\
\hline 5 & $\begin{array}{l}\text { The work colleagues don't show respect to the } \\
\text { privacy of others }\end{array}$ & 3.60 & 1.04 & Moderate \\
\hline 6 & The co-workers at the university are selfish & 3.26 & 1.26 & Moderate \\
\hline 7 & The political views of work colleagues vary & 3.12 & 1.31 & Moderate \\
\hline \multirow[t]{2}{*}{8} & $\begin{array}{l}\text { Some work colleagues use hypocrisy-based methods } \\
\text { when dealing with their superiors }\end{array}$ & 2.97 & 1.33 & Moderate \\
\hline & Total & 3.50 & $\mathbf{0 . 8 0}$ & Moderate \\
\hline
\end{tabular}

Table 3 shows means \& standard deviation calculated for identifying the work colleagues-related reasons leading the faculty members at Hebron \& Al-Quds universities to experience job alienation. Table 3 shows that:

- The overall mean is (3.24) which is a moderate value. The overall standard deviation is $(0.80)$.

- Six statements show moderate means, whereas two statements show high means

- The statement that states (Appreciation and mutual respect are absent between the work colleagues at the university) shows a high mean of (3.91). This mean is ranked first. The standard deviation of the latter statement is (0.93).

- The statement that states (Some work colleagues use hypocrisy-based method when dealing with their superiors) shows a moderate mean of (2.97). The standard deviation of the latter statement is (1.33). These results attributed to the fact that the faculty members do not visit each other. That leads them to experience job alienation. These results may be attributed to the fact that the faculty members do not cooperate with each other. That makes them fear seeing their academic works plagiarized by others.

6.2 Results Related to the Second Question: "Is there any statistically significant difference between the respondents' attitudes which can be attributed to the university?"

In order to provide an answer for the second question, the independent sample t-test was conducted. The results of the latter test are presented in table (4) below:

Table 4. Results of the T-Test for Identifying Whether There Is Any Statistically Significant Difference Between the Respondents' Attitudes Which Can Be Attributed to the University

\begin{tabular}{lllllllll}
\hline No. & Area & University & N. & Mean & $\begin{array}{l}\text { Std. } \\
\text { deviation }\end{array}$ & $\begin{array}{l}\text { Degree of } \\
\text { freedom }\end{array}$ & T value & Sig. \\
\hline Total & Total & Al-Quds University & $\mathbf{1 2 4}$ & $\mathbf{3 . 8 6}$ & $\mathbf{0 . 4 6}$ & 198 & $\mathbf{1 . 9 3}$ & $\mathbf{. 0 6 0}$ \\
& score & Hebron University & $\mathbf{7 6}$ & $\mathbf{3 . 7 3}$ & $\mathbf{0 . 4 6}$ & & & \\
\hline
\end{tabular}


Based on table (4), the significance value (Sig.) indicates that isn't any statistically significant difference -at the statistical significance level of $(\mathrm{a} \leq 0.0 .05)$ - between the respondents' attitudes which can be attributed to the university. That may be attributed to the fact that Jordanian universities have similar pay scales, regulations, bylaws, administrative hierarchies, recruitment policies and number of years of service that entitle faculty members for retirement. It may be attributed to the fact that faculty members at university have similar workload, \& end of service benefit.

\section{Conclusion}

- The analytical descriptive study proved that, the reason of job alienation for the faculty members of Hebron university are not different from the reason of job alienation for the faculty members of Al-Quds University.

- The most common reasons of job alienation in these two universities:

- The bosses do not appreciate the achievements of their subordinates.

- Lack of incentives provided by administration of these universities for their faculty members.

\subsection{Recommendations}

In light of the results, the researchers recommend the following:

- Setting an excellent incentive code and upgrading it regularly. This code must address financial and moral incentives. It must be based on professional standards. It must also reward the excellent and creative faculty members

- Providing attention to the staff social events, and entertainment activities. The researchers also recommend creating an organizational culture that is based on transparency and team work

- Creating an environment that motivates the faculty members. The researchers also recommend holding seminars and competitions for faculty members. That is because the goal-oriented social activities will increase the interaction between them.

- Conducting similar studies that aim at identifying the reasons behind experiencing job alienation by the faculty members at other universities. The researchers also recommend conducting similar studies that aim at identifying the reasons behind experiencing job alienation by other categories at universities, such as: administrators, and students.

\section{Acknowledgment}

The authors would like to thank the administration of the Palestinian Technical University- Kadoorie- for the assistance it has to provide in order to complete this manuscript.

\section{References}

Abed Al-Salam, S. (2003). The concept of alienation from Marcuse's perspective. Al-Ma'refah publishing and distribution house. Cairo: Egypt.

Abu Samra, H., Shuibat, M., \& Muqaddam A. (2014). Job alienation of faculty members at Palestinian universities Field study at Al Quds University and Hebron University. Journal of the Association of Arab Universities for Research in Higher Education, 34(2), 53-71. http://dx.doi.org/10.5032/jae.2004.03022

Al-Dosary, O. (2011). Organizational climate and its relationship with job alienation from the perspective of officers at the General Directorate of the Border Guard in Riyadh. Unpublished MA thesis. Naif University for Security Sciences, Riyadh, Saudi Arabia.

Al-Esawi, A. (1997). Psychology and production. Alexandria: Al-Dar Al-Jame'eye publishing and distribution house.

Al-Ghamri, I. (2002). Human behavior in modern management. Cairo: Dar Al-Jame'at publishing and distribution house.

Al-Hawari, S. (2000). Effective manager. Cairo: Ain Shams Library.

Al-Kuabisi, A. (2003). Training-related psychology: Strategies, techniques, and problems. Studies and Research Center. Naif University for Security Sciences, Riyadh.

Al-Mutrufy, S. (2005). Job alienation and its relationship with performance: A survey-based study targeting the 
employees at the Passport Department at Mecca. Unpublished MA thesis. Naif University for Security Sciences, Riyadh, Saudi Arabia.

Awaad, M. (2011). Job alienation and its relationship with the performance of employees at the Palestinian Legislative Council in Ramallah. Unpublished MA thesis. Al-Quds University. Palestine.

Glaighem, A. (2015). The reality of applying modern technologies and programs and its relationship with empowerment and job alienation among the employees at the Passport Department in Riyadh. $\mathrm{PhD}$ dissertation Naif University for Security Sciences, Riyadh, Saudi Arabia.

Moussa, M. (2003). Manifestations of psychological alienation among the female and male teachers at public schools in the Northern regions of Palestine. Unpublished MA thesis. Najah National University. Nablus Palestine.

Nazem, F., \& Eimani, M. (2014). Investigating the Factors Affecting the Employees Job Alienation in District 2 Of Islamic Azad University. Academy for Environment and life Science, 3(1), 177-191.

Saeed, M. (2017). Job alienation and its relationship with organizational citizenship behavior among the employees at the Ministry of Awqaf and Religious Affairs. Unpublished MA thesis. Al-Aqsa University. Gaza.

Schacht, R. (2015). Alienation. London: Psychology Press. https://doi.org/10.4324/9781315712703

Valikhani, M., \& Soltani, E. (2015). Investigating the Effect of Job Alienation on the Organizational Citizenship Behavior (Branches of Sepah Bank in Shahreza and Dehaghan as Case Study). International Journal of Academic Research in Business and Social Sciences, 5(1), 277-286. https://doi.org/10.6007/IJARBSS/v5i1/1427

Zalikha, J. (2012). Alienation. The Journal of Human and Social Sciences, 8, 346-361. https://doi.org/10.1080/00224545.1986.9713631 